\title{
PENINGKATAN AKTIVITAS DAN HASIL BELAJAR MATEMATIKA MELALUI PENERAPAN COOPERATIVE LEARNING TIPE TIME TOKEN SISWA KELAS VII SMP NEGERI 1 KECAMATAN LAREH SAGO HALABAN
}

\section{Delyetri}

\author{
GURU SMPN 1 KECAMATAN LAREH SAGO HALABAN \\ delyetri67@gmaill.com
}

\begin{abstract}
ABSTRAK.
Tujuan penelitian ini adalah untuk meningkatkan aktivitas dan hasil belajar matematika melalui Penerapan Cooperatif Learning Tipe Time Token siswa kelas VII siswa kelas VII.b dengan jumlah siswa 29 orang.Penelitia ini dilakukan dua siklus dengan instrumen penelitian I dan II. . Penelitian dilaksanakan dalam dua siklus, Secara Berdasarkan hasil observasi aktivitas dan hasil belajar siswa yang diperoleh melalui Penerapan Cooperative Learning Tipe Time Token terjadi peningkatan aktivitas selama pembelajaran dan dapat meningkatkan hasil belajar siswa dalam pembelajaran.Aktivitas kesiapan menghadapi pelajaran dan aktivitas selama pembelajaran pada umunya sudah mengalami peningkatan dan dari hasil ulangan siklus I dan siklus II diketahui bahwa melalui penerapan Cooperative Learning Tipe Time Token dapat meningkatkan hasil belajar siswa. Rata-rata kelas juga mengalami peningkatan dari 58,08 menjadi 67,60 dan banyak siswa yang mencapai SKBM dari 5 orang (20\%) menjadi 19 orang (76\%). Siswa yang nilainya mengalami peningkatan sebanyak 14 orang (56\%).

Kata Kunci: Aktivitas Belajar,Hasil Belajar, Cooperative Learning Tipe Time Token
\end{abstract}

\begin{abstract}
The purpose of this study was to increase the activities and results of learning mathematics through the application of cooperative learning type time tokens for seventh grade students of class VII.b students with a total of 29 students. This research was conducted in two cycles with research instruments I and II. . The research was carried out in two cycles, based on the results of activity observations and student learning outcomes obtained through the Application of Time Token Cooperative Learning, there is an increase in activity during learning and can improve student learning outcomes in learning. Activity readiness to face lessons and activities during learning has generally experienced improvement and from the results of the test cycle I and cycle II it is known that through the application of the Time Token Cooperative Learning Type can improve student learning outcomes. The class average also increased from 58.08 to 67.60 and many students reached SKBM from 5 people (20\%) to 19 people $(76 \%)$. Students whose grades had increased were 14 (56\%).
\end{abstract}

Keywords: Learning Activities, Learning Outcomes, Cooperative Learning Type Time Token 


\section{PENDAHULUAN}

Menurut pengalaman penulis selama mengajar Matematika di SMP Negeri 1 Kecamatan Lareh Sago Halaban terlihat gejala- gejala yang negatif yaitu siswa yang pasif dalam pembelajaran, siswa tidak memperhatikan ketika guru menerangkan pelajaran, malu bertanya karena takut dicemoohkan oleh temannya, tidak mengerjakan pekerjaan rumah, dan tidak mengerjakan tugas-tugas yang diberikan oleh guru. Akibatnya hasil belajar yang mereka peroleh menjadi rendah. Terbukti dari nilai rata - rata semester 1 Tahun Pelajaran. 2018-2019 yaitu 53,17 yang diperoleh siswa kelas VII SMP Negeri 1 Kecamatan Lareh Sago Halaban..Berbagai usaha telah dilakukan oleh penulis agar terlihat aktivitas mereka dalam pembelajaran dan hasil belajar yang mereka peroleh maksimal, yaitu dengan mengadakan kelompok-kelompok belajar, pembelajaran dengan tutor sebaya, memberikan tes setiap akhir pelajaran. Tetapi hasil ini belum memberikan hasil yang maksimal.

Berdasarkan latar belakang masalah dan rumusan masalah yang telah dikemukakan di atas, maka hipotesis dalam penelitian ini adalah : " Aktivitas dan Hasil belajar matematika siswa kelas VII SMP Negeri1 Kecamatan Lareh Sago Halaban dapat ditingkatkan melalu Penerapan Cooperatif Learning Tipe Time Token

Tujuan penelitian ini adalah untuk meningkatkan aktivitas dan hasil belajar matematika melalui Penerapan Cooperatif Learning Tipe Time Token siswa kelas VII SMP Negeri 1 Kecamatan Lareh Sago Halaban

Proses pembelajaran Time Token

Didalam pembelajaran seorang guru dapat menggunakan Time Token dikombinasikan dengan diskusi kelas atau pun diskusi kelompok, proses pembelajaran Time Token ini seperti yang dikemukakan oleh Muslim Ibrahim(2000:51)adalah Mula-mula guru membagikan kartu kepada siswa sama banyak, tiap-tiap kartu berisi waktu berapa lama ia harus bicara,kalau waktu bicara telah habis, maka ia tidak boleh berbicara lagi. Siswa yang sudah kehabisan waktu bicara dapat membantu siswa lain agar bicara. Misalnya menuntun atau memberi semangat akan tetapi ia sendiri tidak boleh lagi berbicara.Agar proses pembelajaran ini dapat berjalan dengan baik maka dibutuhkan seseorang sebagai pemonitor jalannya diskusi. Menurut pendapat Muslim Ibrahim (2004:51)yaitu: Seorang siswa sebagai pemonitor interaksi dan meminta pembicara untuk menyerahkan satu kartu apabila ia telah menghabiskan waktu yang ditetapkan dikartu itu

\section{METODOLOGI PENELITIAN}

Penelitian dilaksanakan di SMP Negeri 1 Kecamatan Lareh Sago Halaban . Waktu penelitian pada Siklus I dilaksanakan tanggal 16 April dan 18 April 2019 dengan materi bangun datar persegi dan persegi panjang dan siklus II dilaksanakan tanggal 23 April dan 24 April dengan materi jajaran genjang dan belah ketupat. Subjek penelitian adalah siswa kelas VII.b SMPN 1 Lareh Sago 
Halaban pada tahun pelajaran 2018-2019 semester 2, dengan jumlah siswa 29 orang.

Penelitian ini menggunakan model siklus, dengan satu siklus memuat 4 komponen yaitu perencanaan, tindakan, pengamatan dan refleksi. Penelitian dilaksanakan dalam dua siklus, masing-masing siklus 4 kali pertemuan. Secara umum rancangan penelittian dalam setiap siklus memuat komponen-komponen berikut:

1. Perencanaan Tindakan

Mengkaji materi yang sesuai dengan kurikulum,Menyusun langkah-langkah rencana pembelajaran, Membuat LKPD,Merencanakan kelompok yang terdiri dari 4 orang dalam satu kelompok,Menyusun lembar latihan dan kunci untuk setiap pertemuan,Menentukan aspek aktivitas yang akan diamati dan menyusun lembar observasi, Menyusun alat evaluasi untuk mengetahui sejauh mana materi yang diberikan telah dikuasai oleh siswa

2. Pelaksanaan Tindakan

Guru membagi siswa secara kelompok yang terdiri 4 orang dan membagikan Lembaran Kegiatan Peserta Didik pada masing-masing siswa,

Meminta siswa mengerjakan LKPD dan mendiskusikannya dengan teman sekelompok.Melaksanakan presentasi setelah siswa selesai berdiskusi dalam kelompok guru memilih secara acak kelompok yang tampil pada hari itui untuk mempresentasikan hasil diskusi mereka. Misalnya kelopmpok A terpilih untuk mempresentasikan hasil diskusinya. Guru membagikan kartu waktu kepada masing-masing anggota kelompok yang tampil sebanyak dua kartu terdiri dari 1 menit. Jadi setiap siswa memiliki waktu sebanyak 2 menit untuk berbicara dalam diskusi tersebut.Guru memilih satu sisswa untuk pemonitor jalannya diskusi sebagai pemonitor waktu. Apabila waktu telah habis untuk satu orang Pemonitor harus memberitahukan kepada pembicara itulah tugas Pemonitor misalnya untuk pertama kali menjelaskan materi ,siswa pertama setiap satu menit berjalan pemonitor akan memukul gendang kecil yang ada di sampingnya, setelah selesai berbicara ia harus menyerahkan kartu waktunya pada pemonitor, begitu selanjutnya. Setelah semua hasil diskusi di jelaskan, siswa lain yang belum mengerti diharapkan bertanya, bagi yang bertanya akan diberikan poin bagi kelompoknya dan individu itu sendiri. Siswa yang menjawab pertanyaan dari kelompok lain hanyalah siswa yang masih memiliki kartu waktu, apabila yang memiliki kartu waktu tidak mampu menjawabnya, ia boleh bertanya kepada teman dalam kelompoknya, yang menerangkan kepada temannya tetap saja siswa yang memiliki kartu waktu, begitu selanjutnya.

3. Pengamatan ( Observation)

Pada tahap ini akan dilihat kegiatan siswa sewaktu guru menyampaikan konsep pembelajaran, berfikir, berdiskusi dalam kelompoknya, dan mempresentasikan hasil diskusi. Semua kegiatan atau aktivitas tersebut dicatat pada lembar observasi oleh seorang observer. Disamping itu kejadiankejadian penting lainnya dicatat dalam bentuk catatan lapangan.

4. Refleksi ( Reflection )

Siklus II dilaksanakan berdasarkan hasil observasi siklus I. Jika pada siklus I tidak terjadi peningkatan aktivitas dan hasil belajar siswa maka dilaksanakan 
siklus II. Kelemahan-kelemahan yang ditemui pada siklus I dijadikan pedoman untuk menyusun kembali perencanaan pada siklus II dan menjadi acuan untuk menentukan tindakan dalam proses belajar mengajar pada siklus II.

Instrumen Penelitian;instrumen pengumpul data yaitu lembar observasi, LKPD dan tes hasil belajar. Lembar observasi digunakan untuk mengetahui aktivitas siswa selama proses belajar mengajar berlangsung. Tes hasil belajar digunakan untuk mengetahui penguasaan siswa terhadap materi yang diberikan pada akhir siklus I dan siklus II.

Teknik Analisis Data;Penelitian ini menggunakan 2 macam teknik analisis data yaitu Teknik persentase dan statistik deskriptif. Teknik persentase digunakan menganalisa data aktivitas siswa dalam pelajaran dengan rumus

$$
\text { Persentase aktivitas }=\frac{\text { Jumlah siswa yang aktif }}{\text { Jumlah siswa seluruhnya }} \quad \text { x } 100 \%
$$

Data hasil observasi diolah dengan persentase dengan kriteria seperti padatabel dibawah ini:

Interval Penilaian Aktivitas Belajar

\begin{tabular}{|l|l|}
\hline $\begin{array}{l}\text { Persentase aktivitas belajar ( AB ) } \\
\text { ( Kwantitatif ) }\end{array}$ & $\begin{array}{l}\text { Sebutan } \\
\text { ( Kwalitatif ) }\end{array}$ \\
\hline $0 \leq \mathrm{AB}<25$ & Sangat sedikit \\
$25 \leq \mathrm{AB}<50$ & Sedikit \\
$50 \leq \mathrm{AB}<75$ & Banyak \\
$75 \leq \mathrm{AB}<100$ & Banyak sekali \\
\hline
\end{tabular}

Dimyati dan Mujiono ( 1992 )

Statistik deskriptif digunakan untuk mengetahui informasi lebih rinci dari satu kelompok data hasil belajar dengan menghitung nilai rata-rata dengan rumus

$$
\mathrm{X}=\frac{1}{n} \sum_{\mathrm{i}=1}^{\sum \mathrm{Xi}}
$$

keterangan :

$\mathrm{X}=$ Rata - rata

$\mathrm{Xi}=$ Nilai setiap siswa

$\mathrm{n}=$ banyak pengikut tes 


\section{HASIL PENELITIAN DAN PEMBAHASAN}

\section{Hasil Penelitian}

Penelitian pada Siklus I dilaksanakan tanggal 16 April dan 18 April 2019 dengan materi bangun datar persegi dan persegi panjang dan siklus II dilaksanakan tanggal 23 April dan 24 April dengan materi jajaran genjang dan belah ketupat pada siswa kelas VII.b semester 2 Tahun Pelajaran 2019/2020. Pada bagian ini dijelaskan hasil penelitian tindakan yang dilakukan yaitu hasil observasi terhadap aktivitas siswa, dan hasil belajar siswa.

\section{Aktivitas siswa pada siklus I}

Berdasarkan hasil observasi diperoleh data aktivitas siswa selama siklus I seperti pada tabel berikut :

Tabel 1 : Hasil Observasi Aktivitas Siswa kelas VII.b SMP Negeri 1 Kecamatan Lareh Sago Halaban

\begin{tabular}{|c|c|c|c|c|c|}
\hline \multirow[t]{3}{*}{ No } & \multirow[t]{3}{*}{ Bentuk Keaktifan Siswa } & \multicolumn{4}{|c|}{ Pertemuan } \\
\hline & & \multicolumn{2}{|c|}{$\mathbf{I}$} & \multicolumn{2}{|c|}{ II } \\
\hline & & $f$ & $\%$ & $f$ & $\%$ \\
\hline 1 & Siswa tidak hadir & 2 & $7 \%$ & 1 & $4 \%$ \\
\hline \multirow[t]{5}{*}{2} & Kesiapan menghadapi pelajaran & & & & \\
\hline & a.Membawa buku catatan & 24 & $86 \%$ & 26 & $93 \%$ \\
\hline & b.Menyiapkan alat-alat pelajaran & 25 & $89 \%$ & 25 & $89 \%$ \\
\hline & c. Menjawab pertanyaan apersepsi & 2 & $7 \%$ & 3 & $11 \%$ \\
\hline & $\begin{array}{l}\text { d.Menyimak tujuan dan manfaat } \\
\text { materi pelajaran melalui time token }\end{array}$ & 26 & $93 \%$ & 27 & $96 \%$ \\
\hline \multirow[t]{6}{*}{3} & Aktivitas selama pembelajaran & & & & \\
\hline & $\begin{array}{l}\text { a. Berbicara sesuai dengan waktu } \\
\text { yang ditentukan }\end{array}$ & 20 & $71 \%$ & 24 & $86 \%$ \\
\hline & b. Menjawab pertanyaan guru & 2 & $7 \%$ & 3 & $11 \%$ \\
\hline & c. Diskusi dengan tertib & 24 & $86 \%$ & 27 & $96 \%$ \\
\hline & d. Mengerjakan LKPD & 26 & $93 \%$ & 27 & $96 \%$ \\
\hline & e. Menanggapi laporan hasil diskusi & 3 & $11 \%$ & 5 & $18 \%$ \\
\hline \multirow[t]{4}{*}{4} & Aktivitas mental & & & & \\
\hline & a.Permisi keluar & 3 & $11 \%$ & 2 & $7 \%$ \\
\hline & b.Bercanda & 2 & $7 \%$ & 1 & $4 \%$ \\
\hline & c.Mengantuk & 0 & $0 \%$ & 0 & $0 \%$ \\
\hline
\end{tabular}

Berdasarkan tabel 3 di atas terlihat bahwa kesiapan siswa menghadapi pelajaran sudah banyak sekali. Tetapi aktivitas menjawab apersepsi sedikit sekali namun pertemuan berikutnya terjadi peningkatan..Aktivitas siswa dalam menjawab pertanyaan guru dari pertemuan ke 1 sampai pertemuan ke 2 mulai meningkat,. Aktivitas siswa diskusi dan mengerjakan LKPD pada pertemuan ke 1 sampai pertemuan ke 2 mengalami kenaikan. Aktivitas menanggapi laporan diskusi tergolong sedikit sekali. Aktivitas mental selama pembelajaran terutama siswa yang mengantuk selama siklus 1 dapat dihilangkan, sedangkan siswa yang 
bercanda dari pertemuan ke 1 sampai pertemuan ke 2 mulai mengalami penurunan.

\section{Hasil Belajar Pada Siklus I}

Setelah diadakan empat pengamatan di akhir siklus I diadakan tes penilaian harian. Adapun nilai yang diperoleh siswa pada tes inu adalah seperti pada

Tabel 2 : Hasil tes siklus I Siswa kelas VII.b SMP Negeri 1 Kecamatan Lareh Sago Halaban

\begin{tabular}{|c|c|c|}
\hline NO & NILAI & TUNTAS \\
\hline 1 & 42 & \\
\hline 2 & 61 & \\
\hline 3 & 61 & \\
\hline 4 & 80 & $\sqrt{ }$ \\
\hline 5 & 42 & \\
\hline 6 & 61 & \\
\hline 7 & 42 & \\
\hline 8 & 61 & \\
\hline 9 & 62 & \\
\hline 10 & 42 & \\
\hline 11 & 41 & \\
\hline 12 & 61 & \\
\hline 13 & 42 & \\
\hline
\end{tabular}

\begin{tabular}{|c|c|c|}
\hline NO & NILAI & TUNTAS \\
\hline 14 & 100 & $\sqrt{ }$ \\
\hline 15 & 42 & \\
\hline 16 & 100 & $\sqrt{ }$ \\
\hline 17 & 100 & $\sqrt{ }$ \\
\hline 18 & 61 & \\
\hline 19 & 43 & \\
\hline 20 & 100 & $\sqrt{ }$ \\
\hline 21 & 22 & \\
\hline 22 & 42 & \\
\hline 23 & 42 & \\
\hline 24 & 60 & \\
\hline 25 & 42 & \\
& & \\
\end{tabular}

Berdasarkan hasil tes di atas nilai yang dicapai oleh siswa belum memuaskan. Nilai rata-rata yang dicapai oleh siswa 58,08. Dan banyak siswa yang mencapai KBM dari 25 siswa ada 5 orang $(20 \%)$.

\section{Refleksi Hasil Pengembangan Siklus I}

Berdasarkan data di atas, pada siklus I masih ditemui beberapa kelemahankelemahan yang ditemukan pada aktivitas siswa. Tes hasil belajar pada siklus I belum memuaskan. Indicator keberhasilan yang dipakai menurut kriteria Dimyati dan Mujiono (Tabel 2).

Aktivitas positif yang memuaskan (banyak) :a.Kesiapan menghadapi pelajaran : membawa buku catatan, menyiapkan alat-alat pelajaran dan menyimak tujuan dan manfaat materi pembelajaran melalui time token.b.Aktivitas selama pembelajaran : diskusi denan tertib, mengerjakan LKPD..Aktivitas positif yang persentasenya tergolong sedikit sekali :c.Aktivitas selama pembelajaran : menanggapi hasil diskusi, menjawab pertanyaan guru.Aktivitas negatif yang sudah dapat dihilangkan :aktivitas mental : mengantuk.Aktivitas negative yang persentasenya sudah mengalami penurunan aktivitas mental : permisi keluar,bercanda.

Hasil belajar yang dicapai siswa pada siklus I belum memuaskan, siswa yang mencapai KBM sebanyak 5 orang (20\%). 
Adapun beberapa kelemahan-kelemahan pada aktivitas siswa selama pembelajaran adalah sebagai berikut:

a. Kemauan siswa menjawab pertanyaan guru masih rendah

b. Kemampuan siswa menanggapi hasil diskusi masih rendah

c. Kemampuan siswa bertanya masih rendah

\section{Revisi Tindakan}

Revisi tindakan yang dilakukan pada siklus I adalah untuk meningkatkan aktivitas siswa pada siklus I. beberapa revisi tindakan yang dilakukan adalah sebagai berikut:

Memberikan reword kepada kelompok yang menanggapi hasil diskusi,Memberikan motivasi pada siswa agar mau bertanya,Menyuruh siswa membaca materi di rumah sebelum guru menyajikan materi tersebut,Memberikan waktu untuk berfikir jika diberikan pertanyaan dan tidak langsung menunjuk siswa

\section{Aktivitas siswa pada siklus 2}

Setelah dilaksanakan pembelajaran berdasarkan revisi tindakan pada siklus I maka dari hasil observasi pada siklus 2 diperoleh dan aktivitas siswa seperti pada tabel 5 berikut :

Tabel 3 : Hasil Observasi Tindakan Selama Siklus 2

\begin{tabular}{|c|c|c|c|c|c|}
\hline \multirow[t]{3}{*}{ No } & \multirow[t]{3}{*}{ Bentuk Keaktifan Siswa } & \multicolumn{4}{|c|}{ Pertemuan } \\
\hline & & \multicolumn{2}{|c|}{ I } & \multicolumn{2}{|l|}{ II } \\
\hline & & $f$ & $\%$ & $f$ & $\%$ \\
\hline 1 & Siswa tidak hadir & 1 & $4 \%$ & 0 & $0 \%$ \\
\hline \multirow[t]{5}{*}{2} & Kesiapan menghadapi pelajaran & & & & \\
\hline & a.Membawa buku catatan & 27 & $96 \%$ & 28 & $100 \%$ \\
\hline & b.Menyiapkan alat-alat pelajaran & 26 & $93 \%$ & 28 & $100 \%$ \\
\hline & c. Menjawab pertanyaan apersepsi & 5 & $18 \%$ & 7 & $21 \%$ \\
\hline & $\begin{array}{l}\text { d.Menyimak tujuan dan manfaat } \\
\text { materi pelajaran melalui time token }\end{array}$ & 27 & $96 \%$ & 27 & $96 \%$ \\
\hline \multirow[t]{6}{*}{3} & Aktivitas selama pembelajaran & & & & \\
\hline & $\begin{array}{l}\text { a. Berbicara sesuai dengan waktu } \\
\text { yang ditentukan }\end{array}$ & 20 & $71 \%$ & 24 & $86 \%$ \\
\hline & a. Menjawab pertanyaan guru & 4 & $14 \%$ & 6 & $21 \%$ \\
\hline & b. Diskusi dengan tertib & 26 & $93 \%$ & 27 & $96 \%$ \\
\hline & c. Mengerjakan LKPD & 26 & $93 \%$ & 28 & $100 \%$ \\
\hline & d. Menanggapi laporan hasil diskusi & 6 & $21 \%$ & 3 & $11 \%$ \\
\hline \multirow[t]{4}{*}{4} & Aktivitas mental & & & & \\
\hline & a.Permisi keluar & 1 & $4 \%$ & 1 & $4 \%$ \\
\hline & b.Bercanda & 1 & $4 \%$ & 0 & $0 \%$ \\
\hline & c.Mengantuk & 0 & $0 \%$ & 0 & $0 \%$ \\
\hline
\end{tabular}


Berdasarkan tabel di atas terlihat kesiapan siswa menghadapi pelajaran sudah sangat banyak sekali .,walaupun kemampuan menjawab pertanyaan guru masih tergolong sedikit Selama pembelajaran terutama dalam diskusi dan mengerjakan LKPD sudah sangat banyak, aktivitas bertanya,diskusi dengan tertib, menjawab pertanyaan sudah mulai meningkat.berbicara menurut waktu yang ditentukan sudah mengalami peningkatan dan menjawab pertanyaaan guru ,menanggapi laporan diskusi sudah mengalami peningkatan..Aktivitas mental siswa yang permisi keluar,bercanda sudah mengalami penurunan dan siswa yang mengantuk sudah dapat dihilangkan.

\section{Hasil Belajar Pada Siklus II}

Setelah diadakan 2 pengamatan di akhir siklus 2 diadakan tes hasil belajar. adapun nilai yang diperoleh siswa pada tes hasil belajar ini adalah seperti tabel berikut ini

Tabel 4 : Hasil tes siklus 2

\begin{tabular}{|c|c|c|}
\hline NO & NILAI & TUNTAS \\
\hline 1 & 80 & $\sqrt{ }$ \\
\hline 2 & 80 & $\sqrt{ }$ \\
\hline 3 & 80 & $\sqrt{ }$ \\
\hline 4 & 80 & $\sqrt{ }$ \\
\hline 5 & 80 & $\sqrt{ }$ \\
\hline 6 & 80 & $\sqrt{ }$ \\
\hline 7 & 80 & $\sqrt{ }$ \\
\hline 8 & 80 & $\sqrt{ }$ \\
\hline 9 & 70 & $\sqrt{ }$ \\
\hline 10 & 70 & $\sqrt{ }$ \\
\hline 11 & 60 & \\
\hline 12 & 70 & $\sqrt{ }$ \\
\hline 13 & 60 & \multicolumn{2}{|}{} \\
\hline
\end{tabular}

\begin{tabular}{|c|c|c|}
\hline NO & NILAI & TUNTAS \\
\hline 14 & 50 & \\
\hline 15 & 80 & $\sqrt{ }$ \\
\hline 16 & 90 & $\sqrt{ }$ \\
\hline 17 & 80 & $\sqrt{ }$ \\
\hline 18 & 70 & $\sqrt{ }$ \\
\hline 19 & 80 & $\sqrt{ }$ \\
\hline 20 & 80 & $\sqrt{ }$ \\
\hline 21 & 50 & \\
\hline 22 & 70 & $\sqrt{ }$ \\
\hline 23 & 80 & $\sqrt{ }$ \\
\hline 24 & 40 & \\
\hline 25 & 10 & \multicolumn{2}{|}{} \\
\hline & \multicolumn{2}{|}{} \\
\hline
\end{tabular}

Berdasarkan hasil nilai tes belajar di atas, hasil belajar yang diperoleh siswa sudah mengalami peningkatan. Nilai rata-rata yang diperoleh 67,60. Siswa yang mencapai KBM 70,00 sebanyak 19 orang (76 \%). Hasil belajar pada siklus 2 mengalami peningkatan hal ini berarti ada peningkatan terhadap penguasaan materi.

\section{Refleksi Hasil Pengembangan Siklus II}

Berdasarkan data di atas hasil belajar siswa cukup memuaskan sedangkan aktivitas siswa ada yang sudah maksimal, ada aktivitas yang belum maksimal tetapi peningkatannya cenderung stabil, ada aktivitas yang belum maksimal tetapi peningkatannya cenderung stabil, ada aktivitas yang belum maksimal tetapi tidak stabil dan aktivitas negative semuanya mengalami penurunan dan ada yang sudah bisa dihilangkan. Adapun aktivitas-aktivitas tersebut adalah sebagai berikut :

Aktivitas yang sudah maksimal (banyak sekali) :Aktivitas selama pembelajaran : diskusi dengan tertib, mengerjakan LKPD,Kesiapan menghadapi pelajaran : membawa buku catatan, menyiapkan alat-alat pelajaran, menyimak.,Aktivitas 
yang belum maksimal tetapi masih dapat ditingkatkan :Aktivitas selama pembelajaran : menjawab pertanyaan.menanggapihasil diskusi,Aktivitas mental yang sudah dapat dihilangkan:Aktivitas selama pembelajaran: mengantuk,Aktivitas mental yang sudah mengalami penurunan aktivitas selama pembelajaran: permisi keluar dan bercanda.

Hasil belajar mengalami peningkatan, siswa yang mencapai KBM sebanyak 19 orang $(76 \%)$. Nilai siswa yang meningkat dari siklus I ke siklus II sebanyak 5 orang $(2 \%)$.

\section{Pembahasan hasil pengembangan pada siklus I dan siklus II.}

Berdasarkan data di atas dapat dilihat perubahan-perubahan yang terjadi pada aktivitas dan pada hasil belajar siswa selama siklus I dan siklus II.

Data hasil pengamatan tanggapan tentang kesiapan menghadapi pelajaran selama siklus I dan siklus II.

Tabel 5. Kesiapan menghadapi pelajaran selama siklus I dan siklus II.

\begin{tabular}{|l|c|c|c|c|}
\hline \multirow{2}{*}{\multicolumn{1}{|c|}{ Aktivitas }} & \multicolumn{4}{c|}{ Pertemuan } \\
\cline { 2 - 5 } & 1 & 2 & 3 & 4 \\
\hline Membawa buku catatan & $86 \%$ & $93 \%$ & $96 \%$ & $100 \%$ \\
\hline Menyiapkan alat-alat pelajaran & $89 \%$ & $89 \%$ & $93 \%$ & $96 \%$ \\
\hline Menjawab pertanyaan apersepsi & $7 \%$ & $11 \%$ & $18 \%$ & $43 \%$ \\
\hline $\begin{array}{l}\text { Menyimak tujuan dan manfaat materi } \\
\text { pelajaran melalui time token }\end{array}$ & $93 \%$ & $96 \%$ & $93 \%$ & $96 \%$ \\
\hline
\end{tabular}

Untuk lebih mudah memahaminya, data diatas disajikan dalam bentuk grafik seperti pada gabar I di bawah ini :

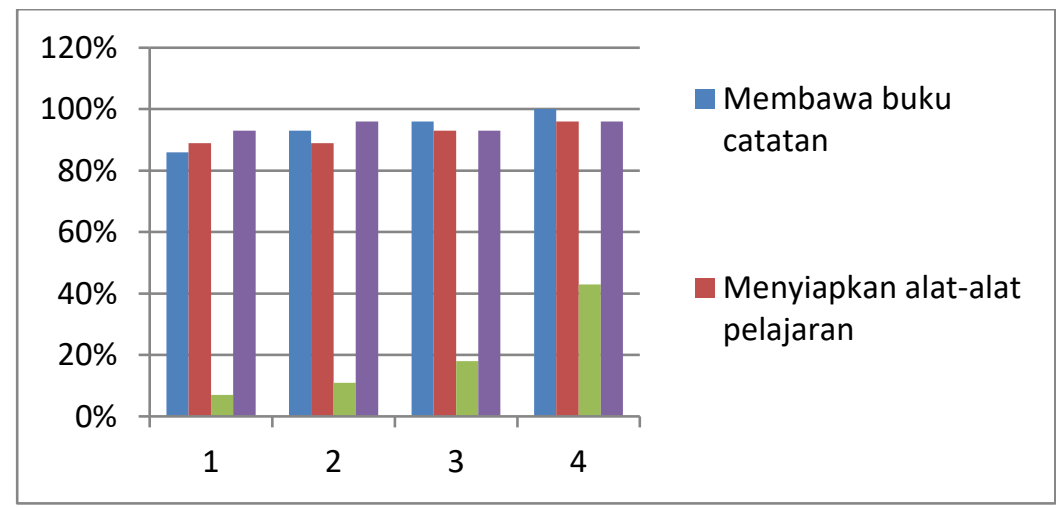

Berdasarkan tabel dan grafik terlihat siswa yang membawa catatan dari pertemuan ke I dan pertemuan ke 4 mengalami peningkaan sampai ke $100 \%$. Hal ini terjadi karena penulis pada pertemuan ke 1 dan ke 4 selalu mengingatkan pada siswa untuk membawa buku catatan karena setiap selesai pertemuan catatan di periksa . Siswa yang menjab pertnyaan apersepsi pada pertemuan ke 1 sampai kepertemuan ke 3 selalu mengalami kenaikan disebabkan. Siswa menyimak tujuan dan manfaat materi melalui time token pada pertemuan ke 1 dan ke 3 , ke 2 
dan ke 4 tidak terjadi kenaikan. Data hasil pengamatan aktivitas selama pembelajaran pada siklus I dan siklus II.

Tabel 6. Aktivitas selama pembelajaran pada siklus I dan siklus II

\begin{tabular}{|l|c|c|c|c|}
\hline \multirow{2}{*}{ Aktivitas } & \multicolumn{4}{c|}{ Pertemuan } \\
\cline { 2 - 5 } & 1 & 2 & 3 & 4 \\
\hline $\begin{array}{l}\text { Berbicara sesuai dengan waktu yang } \\
\text { ditentukan }\end{array}$ & $57 \%$ & $0 \%$ & $71 \%$ & $86 \%$ \\
\hline Menjawab pertanyan guru & $21 \%$ & $11 \%$ & $11 \%$ & $21 \%$ \\
\hline Diskusi dengan tertib & $960 \%$ & $86 \%$ & $93 \%$ & $96 \%$ \\
\hline Mengerjakan LKPD & $86 \%$ & $100 \%$ & $93 \%$ & $100 \%$ \\
\hline Menanggapi laporan hasil diskusi & $18 \%$ & $11 \%$ & $21 \%$ & $11 \%$ \\
\hline
\end{tabular}

Untuk lebih mudah memahaminya, data diatas disajikan dalam bentuk grafik seperti pada gambar 2 dibawah ini

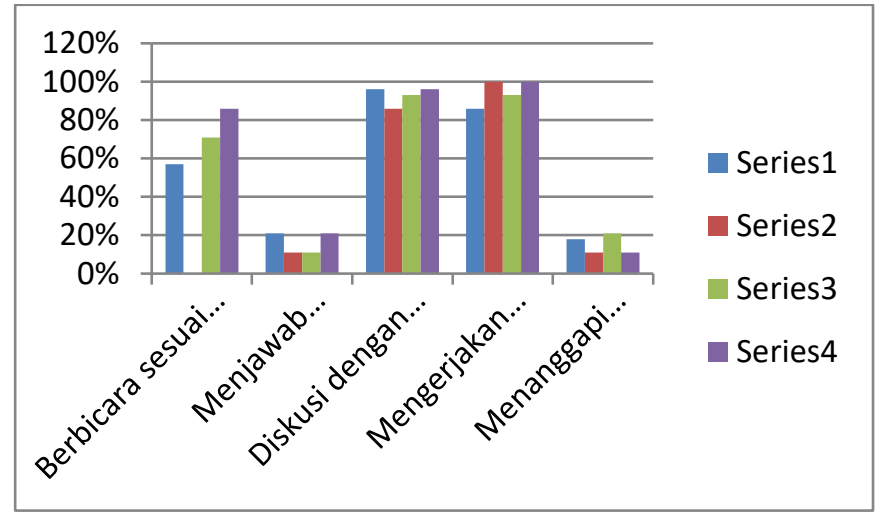

Berdasarkan tabel dan grafik terlihat bahwa aktivitas siswa selama pembelajaran berbicara sesuai dengan waktu yang ditentukan mengalami penurunan. Siswa menjawab pertanyaan guru pada pertemuan ke 2 , ke 3 mengalami penurunan. Siswa diskusi dengan tertib mengalami pada pertemuan ke 2 dan mengalami peningkatan pada pertemuan ke 4 dan siswa yang menanggapi laporan hasil diskusi mengalami penurunan pada pertemuan ke 4,

Data hasil aktivitas mental selama Siklus I dan Siklus II

Tabel 7. Aktivitas mental selama Siklus I dan Siklus II

\begin{tabular}{|l|c|c|c|c|}
\hline \multirow{2}{*}{ Aktivitas } & \multicolumn{4}{c|}{ Pertemuan ke } \\
\cline { 2 - 5 } & 1 & 2 & 3 & 4 \\
\hline Permisi keluar & $7 \%$ & $4 \%$ & $4 \%$ & $4 \%$ \\
\hline Bercanda & $7 \%$ & $0 \%$ & $4 \%$ & $0 \%$ \\
\hline Mengantuk & $0 \%$ & $0 \%$ & $0 \%$ & $0 \%$ \\
\hline
\end{tabular}

Untuk lebih mudah memahaminya, data di atas disajikan dalam bentuk grafik seperti pada gambar 3 di bawah ini : 


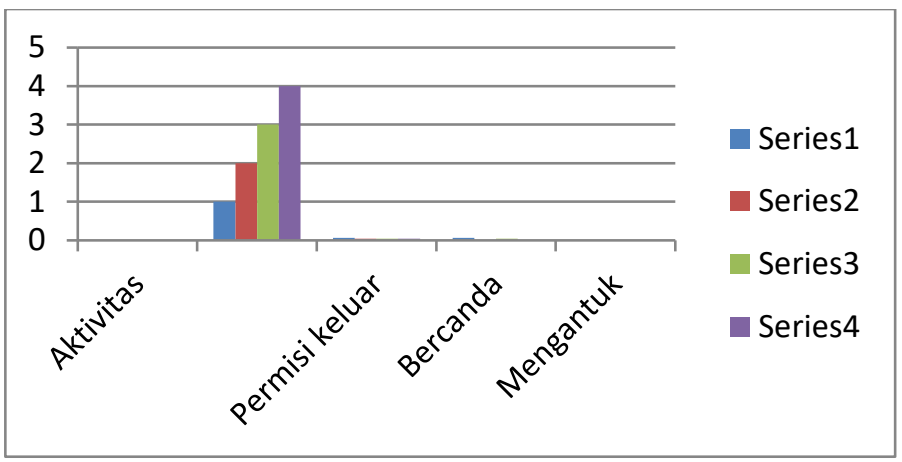

Berdasarkan tabel dan grafik terlihat bahwa siswa permisi keluar pada pertemuan ke 2 sampai ke pertemuan ke 3 tidak terjadi peningkatan. Bercanda dengan teman pada pertemuan ke 4 sudah mencapai titik nol dan siswa tidak ada yang mengantuk dari pertemuan ke 1 sampai pertemuan ke 4 .

Berikut ini diberikan perbandingan hasil ulangan pada siklus I dan siklus II yang diberikan dalam bentuk tabel sebagai berikut :

Tabel 8. Perbandingan hasil analisis ulangan harian pada siklus I dan siklus II

\begin{tabular}{|c|c|c|}
\hline Hasil Analisis & Siklus I & Siklus II \\
\hline Rata-rata & 56,08 & 67,60 \\
\hline Persentase siswa di atas SKBM & $20 \%$ & $76 \%$ \\
\hline
\end{tabular}

Untuk lebih mudah memahaminya, data di atas disajikan dalam bentuk grafik seperti pada gambar di bawah ini :

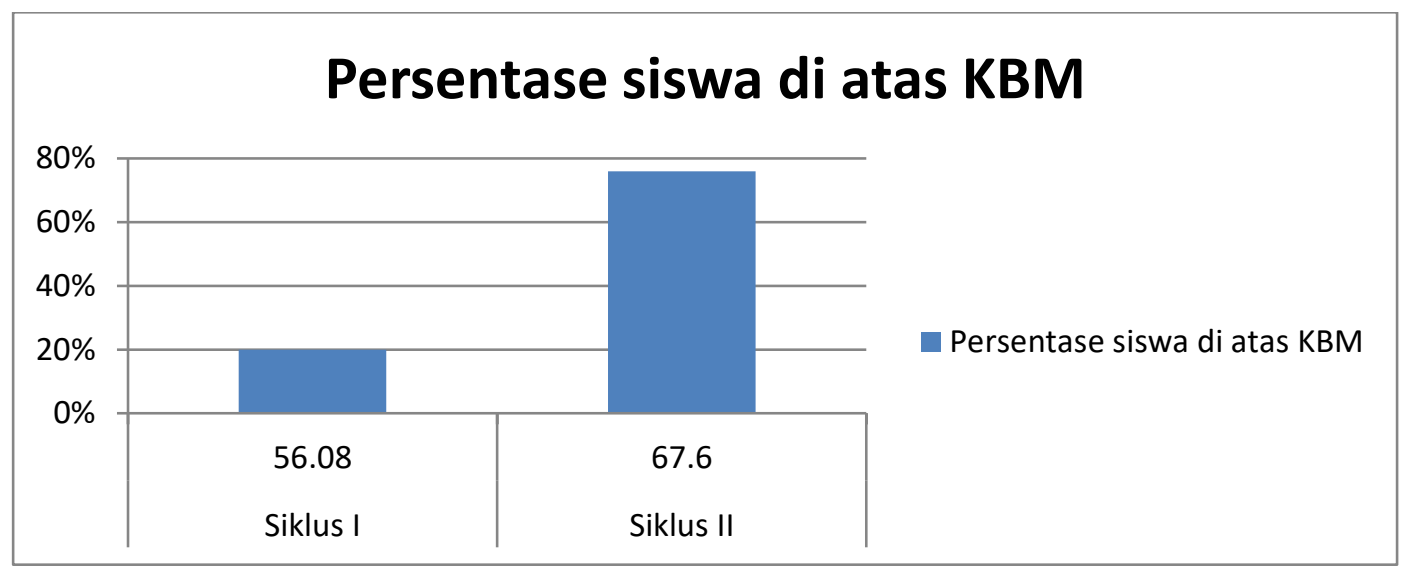

Berdasarkan tabel di atas dapat disimpulkan bahwa kenaikan rata-rata dari siklus I ke siklus II 11,52 dan persentase siswa di atas KBM mengalami peningkatan dari siklus I ke siklus II $56 \%$. 


\section{KESIMPULAN DAN SARAN}

\section{Kesimpulan}

Berdasarkan uraian dan hasil penelitian tindakan berupa penerapan Cooperative Learning Tipe Time Token dapat meningkatkan aktivitas belajar siswa terutama pada aktivitas berbicara sesuai dengan waktu yang ditentukan, diskusi dengan tertib,mengerjakan Lembaran Kegiatan Peserta Didik. Rata-rata kelas juga mengalami peningkatan dari 58,08 menjadi 67,60 dan banyak siswa yang mencapai SKBM dari 5 orang (20\%) menjadi 19 orang (76\%). Siswa yang nilainya mengalami peningkatan sebanyak 14 orang $(56 \%)$.

\section{Saran-saran}

Dari pembahasan yang penulis lakukan dan kesimpulan yang penulis peroleh,maka penulis memberikan saran sebagi berikut:

1. Kepada guru-guru matematika pada umumnya untuk dapat menggunakan metode Cooperative Learning Tipe Time Token untuk memperoleh hasil yang lebih baik.

2. Megingat penelitian ini dilakukan pada materi tertentu maka diharapkan pada penelitian selanjutnya agar dapat melakukan penelitian pada materi lain pada pelajaran matematika.

\section{DAFTAR PUSTAKA}

Almash, Lutfian, dkk. (1998). Pedoman Penelitian Tindakan Kelas. Padang Jurusan Pendidikan Matematika FMIPA IKIP Padang.

Hamalik, Oemar. (1987). Pendekatan Baru Strategi Belajar Mengajar berdasarkan CBSA.

Bandung : Sinar Baru

Ibrahim, Muslim, dkk. (2000). Pembelajaran Kooperatif. Universitas Negeri Surabaya.

Lidia, Nining, (2005). Meningkatkan Motivasi Siswa dengan Pemberian Free Test Awal

Pada Setiap kali Pertemuan. (Skripsi), Program Sarjana UNP Padang Lie, Anita. (2002). Cooperatif Learning. Jakarta : Grasindo

Mulyasa, E. (2006). Menjadi Guru Profesional Menciptakan Pembelajaran Kreatif dan

Menyenangkan. Bandung : Rosdakarya

Sardiman, AM. (1996). Interaksi dan Motivasi Belajar Mengajar. Jakarta : Grasindo

Sujana, Nana. (2001). Penelitian Hasil dan Proses Belajar Mengajar. Bandung : Rosdakarya.

Suherman, Erman, dkk. (2003). Strategi Pembelajaran Matematika Kontenporer. Jica. Universitas Pendidikan Indonesia.

Tim PPPG Matematika Yogyakarta. (2003). Perencanaan Pembelajaran Matematika. Departemen Pendidikan Nasional

Wiwi Juita,(2007). Penerapan Cooperative Learning Tipe Time Token.( PTK)

Nurdyansyah, dan Eni Fariyatul Fahyuni(2016). Inovasi Model Pembelajaran .

Wiwi Juita,(2007.Penerapan Cooperative Learning Tipe Time Token.( PTK) 